\title{
Identifying the Training and Development Needs of Senegalese EFL Instructors Working in Content-specific Areas
}

Dr. Amina Gaye*

Fatima College of Health Sciences, Abu Dhabi, UAE

DOI: $10.36347 /$ sjahss.2020.v08i01.003

| Received: 05.01.2020 | Accepted: 12.01.2020 | Published: 17.01.2020

*Corresponding author: Dr. Amina Gaye

\section{Abstract}

Original Research Article

English is used in all fields of activity and plays an important role in professional areas such as business, tourism, science and technology. This situation has made English for Specific Purposes (ESP) a growing field in Frenchspeaking countries like Senegal and the need for ESP teachers is rapidly increasing in this part of the world. English is now taught in every college department with the goal to produce graduates who meet the requirements of their chosen field of study. Applied linguists have been exploring learners' needs in ESP in many parts of the world in order to design curricula that meet the job market's requirements. However, there has been less research focusing on the instructors' training needs. As a matter of fact, there is a big gap between the goals of the English instructional program and the learners' needs and expectations. In Senegal, graduates realize when they start looking for jobs that their level in English does not meet the labor market needs. Using a mixed-method approach, the purpose of this study is to determine whether the fact that Senegalese graduates are not able to communicate effectively in job situations is due to the instructors' lack of training or not. It also aims to identify the training needs of Senegalese EFL instructors working in content-specific areas in order to improve the teaching of ESP in Senegal.

Keywords: ESP, Needs Analysis, Content-based Curricula, Senegalese EFL Instructors, Training Needs.

Copyright @ 2020: This is an open-access article distributed under the terms of the Creative Commons Attribution license which permits unrestricted use, distribution, and reproduction in any medium for non-commercial use (NonCommercial, or CC-BY-NC) provided the original author and source are credited.

\section{INTRODUCTION}

In many African countries, foreign languages like French, English, or Portuguese serve as official languages, national or intercultural lingua franca and as languages for international communication. However, the role of English as an international language has made its study a necessity. English is now taught in every college department with the goal to produce graduates who meet the requirements of their chosen field of study. In Senegal, where English is taught as a foreign language, the study of English is not optional. It is part of the national curriculum and students have to choose it as the first foreign language to study in middle school. English is also used in all fields of activity and plays an important role in professional areas such as business, tourism, science and technology. Although the working language is French, English is present in the workplace. Many American, British or Chinese companies are indeed setting up in this part of the world, and a mastery of the English language is now required in most job advertisements. Professionals who now need English for written as well as oral communication for their job responsibilities are therefore obliged to study that language.
This situation has made ESP a growing field in French-speaking countries like Senegal and the need for ESP teachers is rapidly increasing in this part of the world. Before the 1960s, the teaching of ESP was seen as a separate activity within the field of English Language Teaching (ELT). Since the 1960s, ESP has become a vital and innovative discipline within the teaching of English to Speakers of Other Languages (TESOL), and has played an important and influential role in ELT.

Researchers have been exploring learners' needs in ESP in many parts of the world in order to design curricula that meet the job market's requirements. However, there has been less research focusing on the instructors' training needs. Indeed, despite the fact that applied linguists have been exploring learners' needs in ESP, there has been less research focusing on the needs of EFL ESP instructors in French-speaking countries, particularly in West Africa, where the teaching/learning of ESP is unfortunately not very developed. As a matter of fact, there is a big gap between the goals of the English 
instructional program and the learners' needs and expectations.

In Senegal, graduates realize when they start looking for jobs that their level in English does not meet the labor market needs. Such a situation made me wonder why those professionals, after taking English classes for many years, had not acquired the skills necessary to use the language effectively in their jobs, but also question their instructors' efficiency. EFL instructors working in content-specific areas are indeed supposed to teach a type of English different from general English - that is, ESP. However, are they aware of the difference between general English and ESP? In Senegal, doctoral students from the English department are usually hired as part-time instructors to teach English in the departments of law, science, medicine, economics, engineering, etc. without any formal training in ESP to meet the students' needs. They usually do not receive any training prior to teaching those content-specific courses, and there is no formal professional supervision to help teaching assistants develop and improve their skills. They are just asked to focus on vocabulary through the reading comprehension of texts related to those content-specific fields. However, ESP is not limited to the teaching of vocabulary through reading comprehension. It involves other aspects of language proficiency including the sociocultural context.

The purpose of this study is to determine whether the fact that Senegalese graduates are not able to communicate effectively in job situations is due to the instructors' lack of training or not. Indeed, if graduates do not meet the job market requirements, it is probably because they do not receive the adequate training they need. Therefore, my objective in dealing with this research study is to identify the training needs of content-specific areas to help EFL teachers in Senegal develop. Training needs should be identified before trying to implement any training solutions. Therefore, this paper aims to help Senegalese instructors working in content-specific areas become aware of the difference between General English and ESP and understand their implications on ELT.

\section{LITERATURE REVIEW}

Hiring general English teachers in technical and vocational schools is a common practice in Africa, particularly in French-speaking Africa. In a paper titled "Pre-Service ESP Teacher Training in an African French-Speaking Country: The Case of Cote d'Ivoire," Kone [1] describes the situation in Ivory Coast and how the Ministry of Technical and Vocational Education recommended the training of all pre-service ESP teachers a few years ago. Kone, who was at that time the director of the Technical and Vocational Teacher Training Institution, goes on to explain how he implemented a pre-service ESP teacher-training course in Ivory Coast by providing training in both technical and vocational content-based instruction and ESP/ELT pedagogy. Building from his own experience and from the literature, he came up with a course based on learning concepts, vocabulary and jargon from the various domains such as Business and Commerce, Secretarial English, Scientific English, and Technical English (English for Science and Technology, Electricity and Electronics, Mechanics, Civil Engineering, Computing, etc.). He particularly focused on curriculum design, teaching methodology, and their implementation.

According to him, the main purpose of that national project funded by the British government was the professional development of ESP teachers. Thanks to that project, the Centre for Resources in English for Specific Purposes (CERESP), now named Centre d'Anglais de Spécialité, was established in Cote d'Ivoire in 1988. The project carried about 2,000 items in course books, audio and video tapes, and reference books with the help of official development assistance and the British Council. It helped train 22 teachers abroad in ESP in Great Britain (In-Service Teacher Training, INSETT), 6 teachers got their Master's Degree in Applied Linguistics, and two others got their Ph.D. in Applied Linguistics. Locally its staff taught ESP in other fields of the Institute and looked after the professional development of ESP teachers by organizing class visits, seminars, and workshops and advising teachers visiting the CERESP. Kone [1] argues that, the pre-service training of ESP teachers has indicated the following:

1. It is possible to design a pre-service ESP teacher training course including both content-based and methodology learning.

2. Basic knowledge in business, science, and technology is necessary in rendering an ESP teacher operational in nearly all technical and vocational fields.

3. Teachers trained this way, that is, using the genre approach, build on the basic knowledge they have acquired.

A similar project was attempted in Senegal by Ndeye Bineta Mbodj, an EFL instructor working in content-specific areas. Mbodj [2] explains that EFL instructors in Senegal need additional training as well as appropriate materials for effective ESP teaching/learning. After she took a class on ESP offered online by the University of Maryland and the University of Oregon in the summer of 2011, Mbodj wanted to raise her colleagues' awareness about the importance of ESP knowledge when teaching in content-specific areas. In collaboration with those universities, she came up with a project titled "Setting and Achieving Goals in ESP: Workshops for Senegalese In-Service Junior and High School EFL Teacher Trainers" funded by the U.S. embassy. Mbodj led a 4-day workshop to train 52 inservice teacher trainers in ESP, who, in turn, train the junior and high school EFL teachers (general as well as 
content-specific area instructors) in all 14 regions of Senegal. Her purpose in dealing with such a project was to equip EFL instructors with sufficient knowledge of ESP to successfully address learners' needs and goals. However, such a project has not been evaluated yet, and it would be interesting to see how those teachers' attitudes have changed after they attended the workshop.

In 2015, Gaye published an article entitled Assessing the needs of the Professionals working in the fields of Business and Tourism in Senegal. Gaye's main objective in this study was to find the needs in English of the professionals working in the fields of tourism and business in Senegal, and based on the research findings, design curricula and propose materials and teaching methodologies to better train those professionals. She investigated the professional community of Saint-Louis, in Senegal, and tried to locate opportunities for English practice. After a thorough analysis of the data collected through observation and surveys, she discovered that despite its status of foreign language in Senegal, English plays a great role in the professional environment, particularly in Saint-Louis where the research was conducted. Professionals need English for both written and oral communication according to their job responsibilities. However, most of them find difficulties communicating effectively in English at their jobs. In an attempt to help better train those professionals, Gaye came up with a curriculum of 18 units designed for the professionals in the field of tourism as well as the professionals in the field of business. That course program, which intends to help those professionals develop the skills necessary to understand and communicate in job situation can further be nationally implemented and evaluated to assess its effectiveness.

Nevertheless, one can wonder what the problem is, and whether those professionals are actually taught what they need to be taught. Indeed, if students are not taught what they need to be taught, it is actually because the teachers have not been effectively trained to consider their needs. This present study will therefore be a continuation of Gaye's previous work and will focus on the teachers' training needs rather than the students' learning needs, for better teaching and learning of ESP in Senegal.

\section{METHODOLOGY}

A mixed-method approach was used in this research study to identify and assess the training needs of Senegalese EFL instructors working in content- specific areas. EFL instructors working in contentspecific areas were given a questionnaire to get an idea of their qualifications and training in ESP. Ninety-two (92) instructors participated in the survey.

Some key informants leading the institutions where the study was conducted were also interviewed to ask about the level of proficiency in English they expect from both the instructors and the students; among them, directors of technical and vocational high schools and the head of the department of English of the University of Dakar. The head of the English department at 'FASTEF,' the department where English teachers are trained at the University of Dakar, was also interviewed to find out whether ESP is taught as a subject to future EFL/ESP instructors or not.

The first informant was Pierre Claver Pouye, the director of the British Senegalese Institute. Pouye is one of the pioneers in the teaching of ESP in Senegal. He was trained at Ecole Normale Superieure (now FASTEF) as an EFL instructor, and had taught in Senegalese technical and vocational high schools for years. He also studied ESP in England and was taught by the famous 'fathers' of ESP Hutchinson \& Waters. He was interviewed in his office for more than 2 hours to know about the constraints EFL instructors working in content-specific areas are facing in Senegal.

Two EFL instructors working in contentspecific areas were also interviewed, one of them being Ndeye Bineta Mbodj, who organized a workshop sponsored by the U.S. embassy to train her colleagues in ESP some years ago. After she took a class on ESP offered online by the University of Maryland and the University of Oregon in summer 2011, Mbodj wanted to raise her colleagues' awareness about the importance of ESP knowledge when teaching in content-specific areas. In collaboration with those universities, she came up with a project titled "Setting and Achieving Goals in ESP: Workshops for Senegalese In-Service Junior and High School EFL Teacher Trainers" funded by the U.S. embassy. I traveled to Thies (one region in Senegal) to meet Mbodj in the technical high school where she works, and our interview lasted approximately an hour and a half during which she explained a lot about preservice and in-service training of Senegalese EFL instructors as well as what prevents instructors working in content-specific areas from teaching more ESP.

Overall, each interview lasted between 30 and 60 minutes and based on the findings, some recommendations for the professional development of ESP instructors in Senegal were made. 


\section{RESULTS}

The results of the survey illustrated in Table 1 and Figure 1 below show that the majority of the participants have completed their graduate studies. Sixty-two percent $(62 \%)$ hold a Master's degree. Twenty-one percent $(21 \%)$ have a doctorate degree, and the remaining $17 \%$ hold a graduate certificate.

Table-1: Highest Degree Completed

\begin{tabular}{|l|l|l|}
\hline Answer & Number & Percentage \\
\hline Bachelor's & 0 & $0 \%$ \\
\hline $\begin{array}{l}\text { Graduate Certificate or } \\
\text { Magister }\end{array}$ & 16 & $17 \%$ \\
\hline Master's & 57 & $62 \%$ \\
\hline Ph.D. or Doctorate & 19 & $21 \%$ \\
\hline Total & $\mathbf{9 2}$ & $\mathbf{1 0 0 \%}$ \\
\hline
\end{tabular}

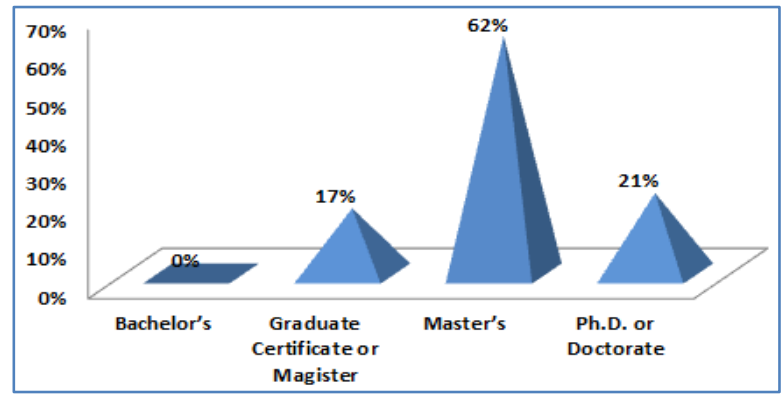

Fig-1: Highest degree completed

Table 2/Figure 2 and table 3/figure 3 reveal that $68 \%$ of the instructors who participated in the survey attended a teacher training school. Among them, the majority $(76 \%)$ have completed a CAEM teaching certificate from FASTEF, the Senegalese teacher training department of the University of Dakar. CAEM is a certificate that allows them to teach in secondary school. Twenty-four percent $(24 \%)$ completed a CAES, a certificate that allows them to teach in high school and requires 2 years of training. However, the remaining $32 \%$ did not attend any teacher training school.
Table-2: Teacher Training School Attendance

\begin{tabular}{|l|c|c|}
\hline Answer & Number & Percentage \\
\hline Yes & 63 & $68 \%$ \\
\hline No & 29 & $32 \%$ \\
\hline Total & $\mathbf{9 2}$ & $\mathbf{1 0 0 \%}$ \\
\hline
\end{tabular}

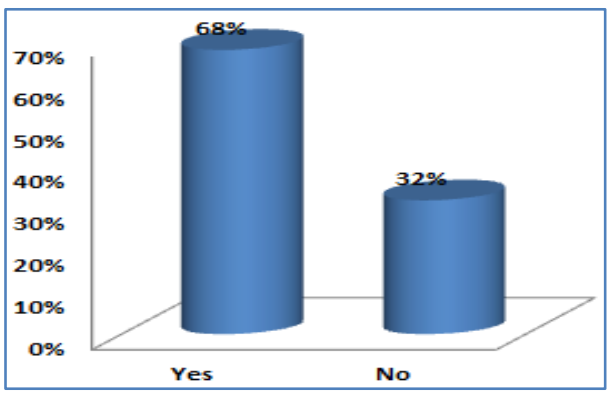

Fig-2: Teacher training school attendance

Table-3: Degree Completed in Teacher Training School

\begin{tabular}{|l|c|c|}
\hline Answer & Number & Percentage \\
\hline CAES & 15 & $24 \%$ \\
\hline CAEM & 48 & $76 \%$ \\
\hline CACEM & 0 & $0 \%$ \\
\hline Total & $\mathbf{6 3}$ & $\mathbf{1 0 0 \%}$ \\
\hline
\end{tabular}

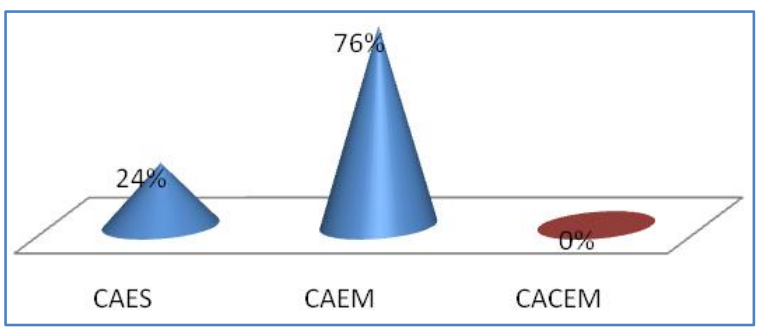

Fig-3: Degree completed in teacher training school.

As seen in Table 4 and Figure 4, business is the field of study where English is mostly taught, followed by tourism, engineering, law, and health. In universities, English is mostly needed in the departments of business (97\%) and tourism (79\%). In technical high schools, English is needed in the fields of business or commerce $(79 \%)$ and engineering $(51 \%)$.

Table-4: Content-Specific Areas Taught

\begin{tabular}{|l|l|l|l|l|l|l|l|l|l|l|l|}
\hline \multirow{2}{*}{ Teachers } & \multicolumn{4}{|l|}{ Answers } & \multicolumn{4}{|l|}{ Total } & \multicolumn{4}{|c|}{ Percentage } \\
\cline { 2 - 11 } & Eng. & Tour. & Bus. & Health & Law & & E. & T. & B. & H. & L. \\
\hline $\begin{array}{l}\text { High } \\
\text { school }\end{array}$ & 27 & 0 & 42 & 0 & 0 & $\mathbf{5 3}$ & $51 \%$ & $00 \%$ & $79 \%$ & $00 \%$ & $00 \%$ \\
\hline University & 11 & 31 & 38 & 09 & 17 & $\mathbf{3 9}$ & $28 \%$ & $79 \%$ & $97 \%$ & $23 \%$ & $43 \%$ \\
\hline
\end{tabular}

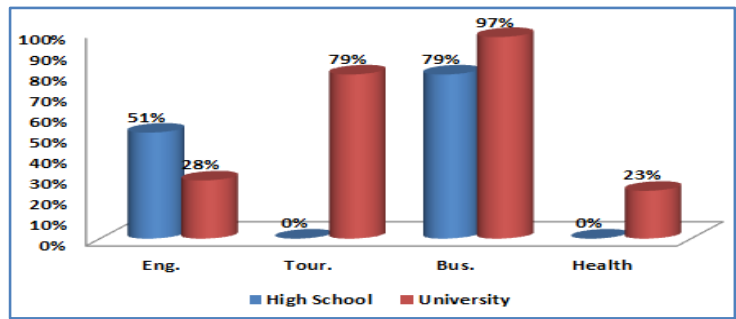

Fig-4: Content-specific areas taught

Table 5 and Figure 5 indicate that $51 \%$ of the professionals surveyed have no professional experience with the type of ESP taught. However, $29 \%$ did some academic research related to the field of study in which they teach English, and $20 \%$ have done some translation services related to the type of ESP taught. 
Table-5: Professional Experience with the Type of ESP Taught

\begin{tabular}{|l|l|l|}
\hline Answer & Number & Percentage \\
\hline Translation & 18 & $20 \%$ \\
\hline Academic research & 27 & $29 \%$ \\
\hline Other (specify) & 0 & $0 \%$ \\
\hline None of the above & 47 & $51 \%$ \\
\hline Total & $\mathbf{9 2}$ & $\mathbf{1 0 0 \%}$ \\
\hline
\end{tabular}

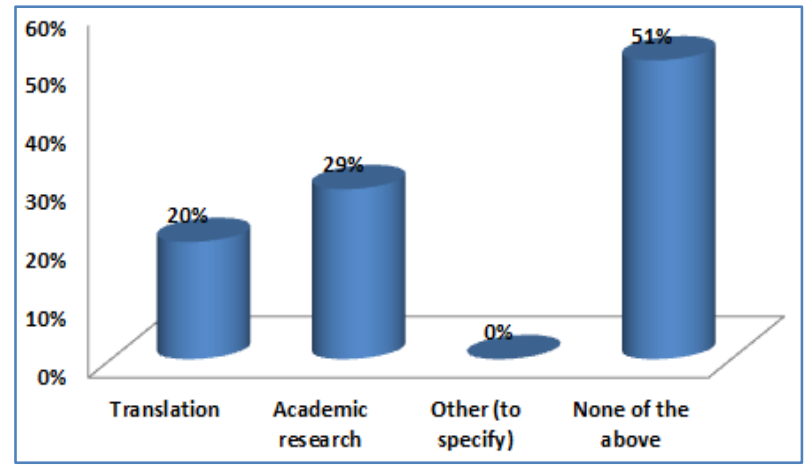

Fig-5: Professional experience with the type of ESP taught

Table 6 and Figure 6 show that $83 \%$ of the instructors surveyed are not required to turn in a syllabus before starting to teach a class.

Table-6: Are You Required to Turn in a Syllabus Before Starting to Teach Any Classes?

\begin{tabular}{|l|l|l|}
\hline Answer & Number & Percentage \\
\hline Yes & 16 & $17 \%$ \\
\hline No & 76 & $83 \%$ \\
\hline Total & $\mathbf{9 2}$ & $\mathbf{1 0 0 \%}$ \\
\hline
\end{tabular}

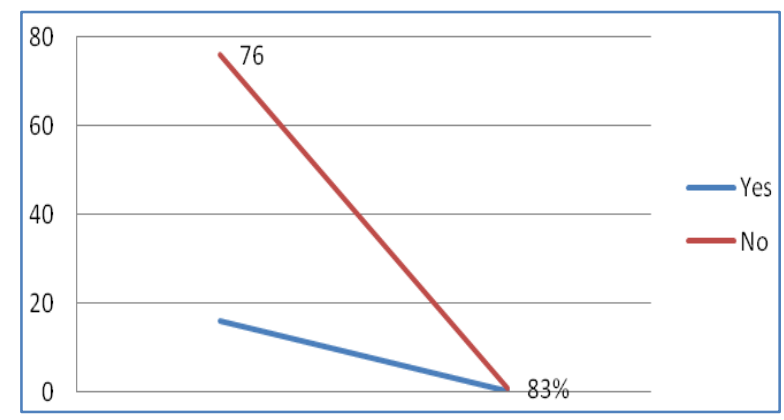

Fig-6: Syllabus requirement

As shown in Table 7 and Figure 7, the majority of the instructors $(77 \%)$ asserted that their institution did not design any general curriculum that they must follow.
Table-7: Has Your Institution Designed a General Curriculum that You Must Follow?

\begin{tabular}{|l|l|l|}
\hline Answer & Number & Percentage \\
\hline Yes & 21 & $23 \%$ \\
\hline No & 71 & $77 \%$ \\
\hline Total & $\mathbf{9 2}$ & $\mathbf{1 0 0 \%}$ \\
\hline
\end{tabular}

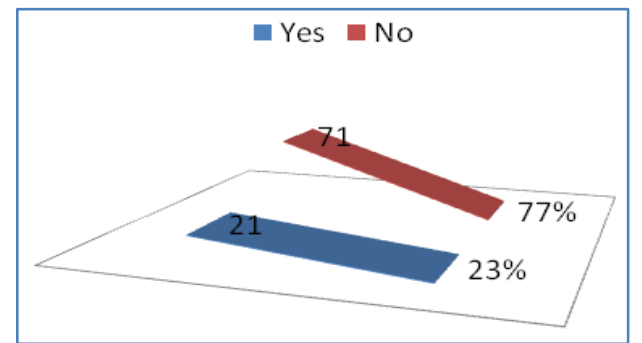

Fig- 7: General curriculum designed in the institution.

As seen in Table 8 and Figure 8, only $20 \%$ of the instructors stated that they have access to a curriculum designed for a type of ESP in their institution.

Table-8: Is There a Curriculum Designed for Any Type of ESP?

\begin{tabular}{|l|l|l|}
\hline Answer & Number & Percentage \\
\hline Yes & 18 & $20 \%$ \\
\hline No & 74 & $80 \%$ \\
\hline Total & $\mathbf{9 2}$ & $\mathbf{1 0 0 \%}$ \\
\hline
\end{tabular}

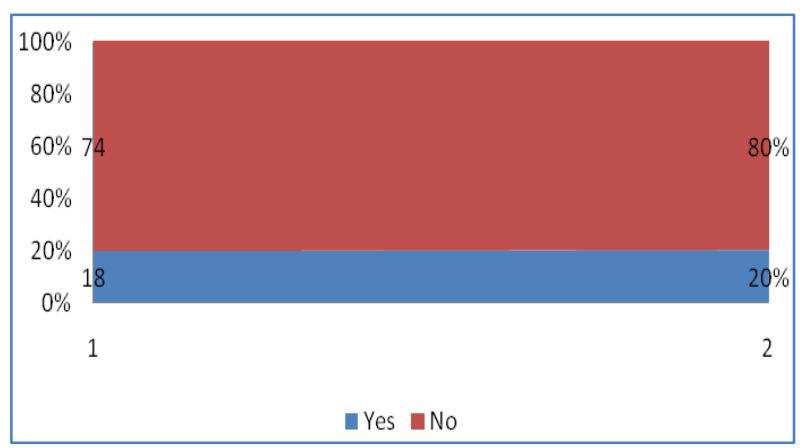

Fig-8: Curriculum designed for any type of ESP

The main field of study in which some institutions have designed an ESP curriculum is engineering (see Table 9 and Figure 9 below). Indeed, $14 \%$ of the instructors surveyed explained that their institution has designed an ESP curriculum in engineering, whereas only $3 \%$ to claimed to have an ESP curriculum in business and $2 \%$ in health and biology. There are no ESP curricula designed in the fields of tourism, law, or finance. 
Table-9: If So, in Which Areas (e.g., Tourism, Business, Finance, Law)

\begin{tabular}{|l|l|l|l|}
\hline Answer & Number & Total & Percentage \\
\hline Tourism & 0 & 92 & $0 \%$ \\
\hline Business & 3 & 92 & $3 \%$ \\
\hline Engineering & 13 & 92 & $14 \%$ \\
\hline Law & 0 & 92 & $0 \%$ \\
\hline Finance & 0 & 92 & $0 \%$ \\
\hline Health/biology & 2 & 92 & $2 \%$ \\
\hline Other (specify) & 0 & 92 & $0 \%$ \\
\hline Total & $\mathbf{1 8}$ & $\mathbf{9 2}$ & $\mathbf{2 0 \%}$ \\
\hline
\end{tabular}

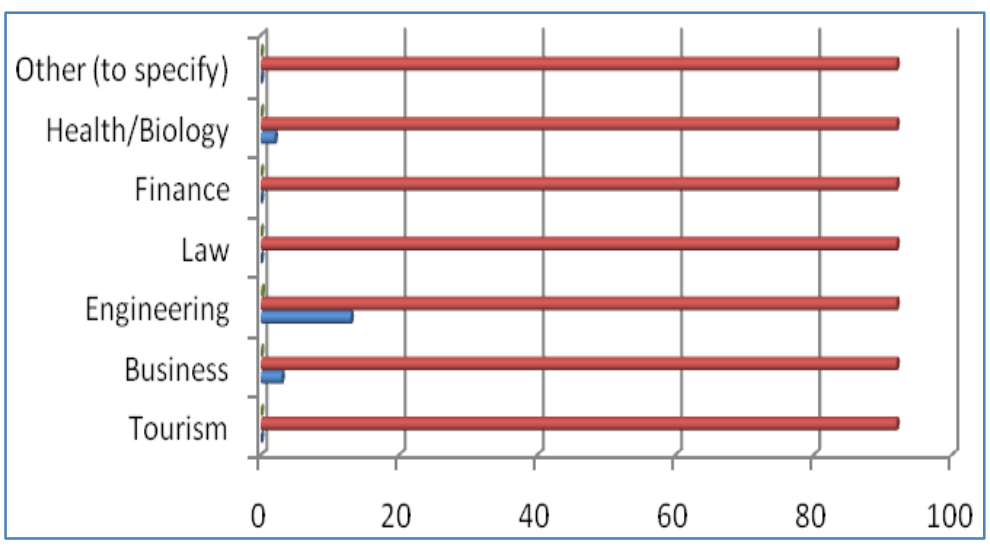

Fig-9: Areas in which an ESP curriculum is designed

In addition to the survey, interviews were also conducted with some of the stakeholders to understand their expectations of the students' level in English when they graduate.

\section{Question 1: Educational background and career experiences}

\begin{tabular}{|l|l|}
\hline Name & Answer/Transcript \\
\hline P. C. Pouye & $\begin{array}{l}\text { Holds a Master's degree in ESP from England. } \\
\text { Former university instructor. } \\
\text { Current Director of the British Senegalese Institute (BSI). }\end{array}$ \\
\hline N. B. Mbodji & $\begin{array}{l}\text { Holds a Master's in English. } \\
\text { Completed an E-Teacher training in ESP sponsored by the U.S. Department of State at the } \\
\text { University of Maryland, Baltimore County. } \\
\text { English instructor at a technical and vocational high school and in the Medical Department of } \\
\text { Thies University. }\end{array}$ \\
\hline Dr. Coly & $\begin{array}{l}\text { PhD in English Studies. } \\
\text { Head of the English Department at FASTEF (the department where future English instructors are } \\
\text { trained in Dakar). }\end{array}$ \\
\hline $\begin{array}{l}\text { PhD in English with a concentration in Literature. } \\
\text { Head of the English Department, Cheikh Anta Diop University, Dakar. }\end{array}$ \\
\hline Respondent & $\begin{array}{l}\text { PhD in English. } \\
\text { English instructor in both the Department of English and the Department of Economics at Cheikh } \\
\text { Anta Diop University, Dakar. }\end{array}$ \\
\hline
\end{tabular}

Question 2: Do you think the English taught in content-specific areas can be considered ESP?

\begin{tabular}{|l|l|}
\hline Name & Answer \\
\hline P.C. Pouye & $\begin{array}{l}\text { 'No. I don't think what is taught in content-specific areas is 'ESP.' The field of ESP is not well known } \\
\text { in Senegal. It is not taught as a subject in college or at FASTEF. Most of the EFL instructors in } \\
\text { content-specific areas are not trained in ESP at all and therefore cannot teach it. They are not even } \\
\text { aware of the difference between general English and ESP. Some hear about the term for the first time } \\
\text { when they start doing research. It is just vocabulary and reading comprehension that are taught in } \\
\text { content-specific areas, not ESP. That is why students, after they graduate from those departments are } \\
\text { not able to communicate effectively in job situations. Yet, what is hilarious about it is that most of } \\
\text { those EFL instructors believe they are teaching ESP simply because they are teaching vocabulary }\end{array}$ \\
\hline
\end{tabular}




\begin{tabular}{|l|l|}
\hline & $\begin{array}{l}\text { words related to their students' field of study." } \\
\text { Do you teach ESP at the British Senegalese Institute (BSI)? } \\
\text { "Of course we make sure what we teach our students and/or professionals is ESP. This institution is } \\
\text { private and people pay a lot of money to get what they need. However, I can't say the same about } \\
\text { public institutions. I think there is a lot to do about the teaching of ESP in those public institutions." }\end{array}$ \\
\hline N. B. Mbodji & $\begin{array}{l}\text { "I don't think it is taught in most of the Senegalese public institutions but I can assure you it is taught } \\
\text { in Thies Technical high school and in the medical department of Thies University. Indeed, since I } \\
\text { completed an E-Teacher training in ESP at the University of Maryland in Baltimore, I became aware } \\
\text { that I was, like many of my colleagues, teaching vocabulary related to the field of study. However, } \\
\text { those students' needs are not just reading texts and learning some English words. They need to } \\
\text { perform the tasks. I therefore, with some of my colleagues, designed curricula for the fields of } \\
\text { engineering and medical studies that most of the teachers here and in Thies university follow. }\end{array}$ \\
\hline Dr. Coly & $\begin{array}{l}\text { "I can't really tell because I personally have never been trained in ESP. I attended a workshop in ESP } \\
\text { but do not really master the field. I know though that it was part of the curriculum at FASTEF some } \\
\text { years ago. However, the instructor who was teaching that subject left for the United States and since } \\
\text { then he has not been replaced. ESP is therefore not currently taught at FASTEF." }\end{array}$ \\
\hline Pr. Kandji & $\begin{array}{l}\text { "ESP is not taught in Cheikh Anta Diop University department of English. We mostly focus on } \\
\text { Literature and cultural studies in this department. However, our instructors teach English in the } \\
\text { University's other content-specific departments. They have not been trained in ESP, but since they are } \\
\text { English instructors, they are in charge of teaching those English classes." }\end{array}$ \\
\hline $\begin{array}{l}\text { Anonymous } \\
\text { Respondent }\end{array}$ & $\begin{array}{l}\text { ESP since we teach students vocabulary related to their field of study through reading comprehension. } \\
\text { Although we are not trained in ESP, we try to find texts that deal with their area of interest and contain } \\
\text { vocabulary words used in their field." }\end{array}$ \\
\hline
\end{tabular}

\section{Question 3: Do you think Senegalese educational authorities take the teaching} of ESP seriously?

\begin{tabular}{|c|c|}
\hline Name & Answer \\
\hline $\begin{array}{l}\text { P. C. } \\
\text { Pouye }\end{array}$ & $\begin{array}{l}\text { "I am one of the pioneers of ESP in Senegal. Since I started my career as an EFL instructor, I have been } \\
\text { working in content-specific areas. Like all my colleagues at that time, I have never been trained in ESP. } \\
\text { However, I would do research on my students' field of study, attend some of their classes and discuss } \\
\text { with their professors to have an idea of their professional needs in English. At the beginning I was just } \\
\text { teaching vocabulary related to their field of study; but after I completed a Master's degree in ESP in } \\
\text { England, I became aware that what I was teaching was not ESP. After I came back, I tried my best to } \\
\text { share that knowledge with my colleagues at Cheikh Anta Diop University. I am now working for the } \\
\text { British Senegalese Institute (BSI), a private institution. Several years have passed since then, and the } \\
\text { situation has still not changed. I think even if educational authorities do take the teaching of ESP } \\
\text { seriously, they need to take it more seriously." }\end{array}$ \\
\hline $\begin{array}{l}\text { N. B. } \\
\text { Mbodji }\end{array}$ & $\begin{array}{l}\text { "I don't think so. There is no general ESP curriculum designed nationwide to meet content-specific } \\
\text { areas' needs. Most of the EFL instructors teaching in content-specific areas are not trained in ESP and } \\
\text { do not even understand the field enough to teach it. Moreover, they are not even required to turn a } \\
\text { syllabus in before teaching a class. The rare workshops in ESP that some of those instructors attend are } \\
\text { usually not organized by educational authorities or the Ministry of Education but by the US Embassy or } \\
\text { the British Council." }\end{array}$ \\
\hline Dr. Coly & $\begin{array}{l}\text { "It's not that they do not take it seriously, it might just be ignorance but also lack of means. We do not } \\
\text { really see how it may totally differ from General English and therefore just train instructors in General } \\
\text { English. I am the head of this department and it is here that future EFL instructors are trained. However, } \\
\text { we do not have any professor that teaches ESP as a subject and many factors can explain that situation: } \\
\text { lack of qualified professors who can teach it but mostly lack of means. Although we would love to hire } \\
\text { as many experts as needed, our means do not allow us to do so." }\end{array}$ \\
\hline Pr. Kandji & $\begin{array}{l}\text { "Well, I am the head of the English department and we do not deal with ESP here. So I cannot really } \\
\text { answer your question." }\end{array}$ \\
\hline $\begin{array}{l}\text { Anonymous } \\
\text { Respondent }\end{array}$ & $\begin{array}{l}\text { "I don't know what you mean by 'seriously' but I can tell you that the Ministry of Education has come } \\
\text { up with a General curriculum that contains guidelines on how to teach English in the different fields of } \\
\text { study. Although it is not a standard syllabus that actually gives details about what to teach and how to } \\
\text { teach it, it tells the instructor about the learning outcomes and the educational authorities' perception of } \\
\text { the students' needs. As a matter of fact, most of the instructors who teach in content-specific areas like } \\
\text { me, are aware that those students need vocabulary related to their field of study." }\end{array}$ \\
\hline
\end{tabular}


Question-4: What do you think should be done to help Senegalese EFL instructors in content-specific areas teach more ESP?

\begin{tabular}{|c|c|}
\hline Name & Answer \\
\hline P. C. Pouye & $\begin{array}{l}\text { "First of all, EFL instructors need to be trained. ESP should be a subject at FASTEF so } \\
\text { that future EFL instructors who will be teaching in vocational high schools understand the } \\
\text { field enough. Also, cross-discipline collaboration needs to be promoted. I remember when } \\
\text { I first started to teach English in a technical high school in Diourbel, I was attending some } \\
\text { Engineering classes just to have an idea of what students do in their field of study. That } \\
\text { helped me a lot in designing my syllabus and classroom activities. That's why I believe } \\
\text { motivation could also be a factor. Indeed, teachers, if interested in what they are doing and } \\
\text { if they are passionate about it, should do research to add to their knowledge and better } \\
\text { meet their students' expectations." }\end{array}$ \\
\hline N. B. Mbodji & $\begin{array}{l}\text { "When I compare what I was doing before I took the online course with what I am } \\
\text { currently doing, I still wonder how I could have taught this before. We should not start } \\
\text { with assumptions, but that's exactly what I was doing. I used to think that for medical } \\
\text { students learning English, whatever is related to healthcare would interest them; and that is } \\
\text { not what is really happening. Their needs are not just reading texts and learning some } \\
\text { English words. They need to perform the tasks. So I would say instructors need to be } \\
\text { trained. That's why after my online training, I decided to pass along those techniques I } \\
\text { learned in a series of workshops for English teachers. I led a four-day workshop, } \\
\text { sponsored by the US Embassy, to train } 52 \text { in-service teacher trainers in ESP, who are } \\
\text { supposed to, in turn, train the junior and high school EFL teachers (General as well as } \\
\text { content-specific areas instructors) in all the fourteen regions of Senegal. My purpose in } \\
\text { dealing with such a project was to equip EFL instructors with sufficient knowledge of ESP } \\
\text { to successfully address learners' needs and goals. Such a project has however not been } \\
\text { evaluated yet, and it would be interesting to see how those teachers' attitude have changed } \\
\text { after they attended the workshop." }\end{array}$ \\
\hline Dr. Coly & $\begin{array}{l}\text { "I would say find a way to train future EFL instructors in ESP. It is here that future EFL } \\
\text { instructors are trained and I agree that ESP should become a subject again in this } \\
\text { institution. Even though they don't have the opportunity to take classes in ESP in college, } \\
\text { they should be able to take some here, at FASTEF." }\end{array}$ \\
\hline Pr. Kandji & $\begin{array}{l}\text { "We don't deal with ESP in the English department, so it won't be easy for me to give } \\
\text { recommendations on its teaching..." }\end{array}$ \\
\hline Anonymous Re & answer, because he firmly believes that what he is teaching is ESP. \\
\hline
\end{tabular}

\section{DISCUSSION}

Ninety-two (92) Senegalese EFL instructors working in content-specific areas were given a questionnaire to assess their training needs in ESP, and interviews were conducted to learn more about the teaching of ESP in Senegal. In the institutions I visited, there were only 2 to 6 English instructors at the most working in content-specific areas in technical high schools; and in universities, it is usually the same professors or teaching assistants who teach in the English Department that also teach English in the other content-specific departments of the university.

The data collected show an immediate need for the development and organization of training courses for Senegalese EFL instructors working in contentspecific areas in order to produce graduates that meet the labor market's requirements and expectations. The findings show that the majority of EFL instructors need training in ESP to better serve their learners' needs. Indeed, $93 \%$ of the instructors surveyed have never taken any classes in ESP. Nevertheless, 55\% claimed to have at least once attended a workshop in ESP. Only $7 \%$ have actually taken some classes in ESP, with $2 \%$ holding a degree or certificate in ESP. However, those $2 \%$ specified that they graduated from British or American universities where they studied ESP. It can therefore be concluded that the majority of the Senegalese EFL instructors working in content-specific areas are not trained in ESP. Instructors do not acquire the skills necessary to teach ESP in Senegal unless they study abroad. Lack of training is actually the main reason why their knowledge of the field is limited.

That lack of preparation for future ESP instructors made me ask the interviewees if they think Senegalese educational authorities take the teaching of ESP seriously. Most of them agreed that more needs to be done to train Senegalese EFL instructors. They stated that EFL instructors working in content-specific areas are not trained in ESP, there is no national ESP curriculum designed for content-specific areas that they can follow, and the rare workshops in ESP that they can attend are not even organized by the Ministry of Education but by the U.S. embassy or the British Council. 
However, they explained that such a situation is due to ignorance and lack of means. Some of the participants believe that because Senegal is a developing country, the Ministry of Education lacks the financial means to regularly organize workshops. In addition, educational authorities are not aware of how critical the situation is - a point of view that I share. Senegal is indeed a French-speaking country, and with English not being the official language of the country, one can understand that educational authorities do not invest to promote it. However, English is currently the language for international communication, and despite its status of foreign language in Senegal, English is present and needed in the professional fields. It is even sometimes used more than French. Therefore, educational authorities need to be aware of the status of that foreign language, as well as the role it plays in the professional sector in Senegal, in order to be willing to put more effort into helping to teach it effectively.

Like in many developing countries, ESP is actually not taught as a subject in any Senegalese universities or at FASTEF, the department where EFL instructors are trained. The head of that department did actually confirm during our interview that ESP is not currently taught as a subject at FASTEF due to a lack of qualified instructors. As a matter of fact, I can assert without any doubt that future EFL instructors who will be sent to technical and vocational high schools are not trained in ESP but only in general English. Unless they come across the term ESP in their research or attend workshops organized or sponsored by the British Council or the U.S. embassy, they might never hear the term.

In addition, the results of this research study show that $64 \%$ of the Senegalese EFL instructors working in content-specific areas do not conduct any needs analysis before designing their syllabus. They are not even required, according to $83 \%$ of the instructors surveyed, to turn in a syllabus before starting to teach a class. One can therefore easily understand why they do not put any effort into assessing their learners' needs and designing their syllabus and materials accordingly. Teachers need to be aware that a needs analysis should be conducted prior to, during, and indeed after any teaching activity in ESP. Theorists [4-6] agree that needs analysis is of primary importance in the teaching of ESP. Such a view echoes that of Mbodji [9] who argues that:

A quick solution to hire untrained teachers to fill a hiring gap - and I will add to cope with a lack of financial means-has created a negative impact on the quality and efficiency of the teaching/learning process. Teachers are merely given a course title with neither content nor guidelines to direct their instruction (p. 2).
Expertise in the ESP discipline taught is an important aspect in the teaching of ESP-business, tourism, and to a smaller extent engineering, law, and health being the major fields where English is needed in Senegal. Many theorists [4, 7] agree that ESP teachers need to combine the skills of the EFL teacher and those of the subject expert. However, 95\% of the instructors surveyed have no content knowledge of the discipline in which they teach English. Worse, 64\% have even no interest at all in the discipline. Also, most of them $(51 \%)$ have no professional experience with the type of ESP taught, neither as translators nor as researchers. However, although it might appear very challenging, Kone [1] believes that lack of expert knowledge in the field is very easy to overcome if there is collaboration between EFL instructors and content experts. Indeed, one of the interviewees believes that lack of training and lack of collaboration between EFL instructors and content experts are the major constraints to effectively teach ESP in Senegal.

\section{CONCLUSION AND RECOMMENDATIONS}

The teaching of English in content-specific areas needs to be adequately supported by teacher preparation. According to Swales [8], all researchers interested in assessing the progress of ESP as a component of ELT agree that one of the most constraining factors to this progress is the lack of specialized teacher-training. However, Mahapatra [9] emphasized that such training is highly context-specific and time-bound, and thus recommends it should be designed on the basis of the needs of the teachers under focus - the teachers under focus in this research study being Senegalese EFL instructors working in contentspecific areas. A thorough analysis of their training needs has made me come up with recommendations that can help better train them in ESP in order to reduce the gap between learners' achievements and the actual societal and professional needs.

Based on the results of this research, my main recommendation is to urge Senegalese educational authorities and policy makers to accompany EFL instructors in their transition from EFL to ESP teachers. In addition to promoting collaboration between EFL instructors and content experts, pre-service as well as in-service training is necessary for the professional development of those instructors. Pre-service and inservice training will indeed better prepare EFL instructors working in content-specific areas to become effective ESP practitioners.

\section{REFERENCES}

1. Kone Z. Pre-service ESP teacher training in an African French-speaking country: The case of Cote d'Ivoire. English for Specific Purposes World. 2007;14(6). Retrieved from http://www.espworld.info/Articles_14/Preservice_ESP _teacherTraining.htm 
2. Mbodj NB. Setting and achieving goals in ESP: Workshops for Senegalese in-service junior and high school EFL teacher trainers. Paper presented at the E-Teacher Professional Development Workshop, University of Oregon. 2011. Retrieved from http://umbc.uoregon.edu/eteacher/projects /201004_E-Teacher_PD_Mbodj.pdf

3. Gaye A. Assessing the English Language Needs of the Senegalese Professionals Working in Business and Tourism Sectors in Saint-Louis, Senegal. International Journal of English Language and Translation Studies. 2016;3(4), 01-15.

4. Dudley-Evans T and St. John MJ. Developments in English for specific purposes: A multidisciplinary approach. Cambridge, England: Cambridge University Press.1998.

5. Hutchinson T and Waters A. English for specific purposes. A learning-centred approach.
Cambridge, England: Cambridge University Press.1987.

6. Munby J. Communicative syllabus design. Cambridge, England: Cambridge University Press.1987.

7. Ferguson G. Teacher education and LSP: The role of specialized knowledge. In R. Howard \& J. Brown (Eds.), Teacher education for LSP. Clevedon, England: Multilingual Matters.1997: 80-89

8. Swales J. Episodes in ESP: A source and reference book on the development of English for science and technology, Volume 1. Oxford, England: Pergamon Institute of English.1985.

9. Mahapatra SK. Teacher training in ESP: A historical review. English for Specific Purposes World. 2011;33 (11). 